\title{
Effects of pre-storage calcium applications on physical and chemical attributes of potato*
}

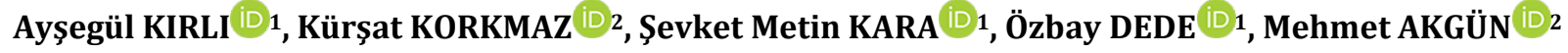 \\ ${ }^{1}$ Department of Field Crops, Faculty of Agriculture, Ordu University, Ordu \\ ${ }^{2}$ Department of Soil Science and Plant Nutrition, Faculty of Agriculture, Ordu University, Ordu
}

*This study was orally presented at 1st International GAP Agriculture and Livestock Congress, 24-27 April, URFA, 2018. The authors are grateful to Ordu University Scientific Research Projects Coordination Unit for providing financial support for this work under Project No. HD-1619.

Alınıș tarihi: 3 Ekim 2019, Kabul tarihi: 28 Kasım 2019

Sorumlu yazar: Kürşat KORKMAZ, e-posta: korkmaz60@gmail.com

\begin{abstract}
Pre-storage applications are of considerable importance in reducing chemical and physiological changes occurring in potato tubers during prolonged storage. The objective of this study is to determine the effect of increasing doses of pre-storage applied calcium on physical and chemical properties of potato tubers. The experiment was carried out in a completely randomized design with three replications at cold storage with $+4{ }^{\circ} \mathrm{C}$ temperature and $85-90 \%$ moisture. The potato tubers were soaked in three calcium solutions $(5 \%, 10 \%$ and $15 \%$ ) for one hour, along with the control (pure water). The calcium pretreatments showed significant ameliorative effects on all physical and chemical attributes of four months stored potato tubers. With calcium application, sprouting tuber rate and shooting length decreased by $15 \%$ and $42 \%$ as compared to the control, respectively. The prestorage applications of calcium significantly reduced the losses occurring in total phenolic content and antioxidant activity during storage. In conclusion, the present study suggested that pre-storage calcium applications could reduce storage losses in potato tubers.
\end{abstract}

Key words: Antioxidant activity, Solanum tuberosum, shooting tuber, total phenolic content

\section{Depolama öncesi kalsiyum uygulamalarının patatesin fiziksel ve kimyasal özellikleri üzerine etkisi}

Öz

Depolama öncesi yapılan ön uygulamalar, uzun depolama süresi sırasında patates yumrularında meydana gelen kimyasal ve fizyolojik değişikliklerin azaltılmasında büyük öneme sahiptir. Bu çalışmanın amacı, depolama öncesinde uygulanan artan kalsiyum dozlarının patates yumrularının fiziksel ve kimyasal özellikleri üzerindeki etkisini belirlemektir. Araștırma, $+4{ }^{\circ} \mathrm{C}$ sıcaklık ve \%85-90 neme sahip soğuk hava deposunda 3 tekerrürlü olarak, tesadüf parselleri deneme desenine göre yürütülmüştür. Patates yumruları, kontrol (saf su) ile birlikte 3 farklı kalsiyum çözeltisine $\quad(\% 5, \quad \% 10$ ve $\% 15)$ daldırılmıştır. Kalsiyum ön uygulamaları, dört aylık depolama süresi boyunca patates yumrularının incelenen tüm fiziksel ve kimyasal özellikleri üzerinde olumlu etkiler göstermiștir. Kalsiyum uygulaması ile sürgün veren yumru oranı ve sürgün uzunluğu kontrole göre sırasıyla $\% 15$ ve $\% 42$ oranında azalmıştır. Depolama öncesi kalsiyum uygulamaları, depolama sırasında toplam fenolik madde içeriği ve antioksidan aktivitede meydana gelen kayıpları önemli ölçüde azaltmıştır. Sonuç olarak, bu çalışma, depolama öncesi kalsiyum uygulamalarının patates yumrularında meydana 
gelen depolama kayıplarını azaltabileceğini göstermiştir.

Anahtar kelimeler: Antioksidan aktivite, Solanum tuberosum, sürgün veren yumru oranı, toplam fenolik madde miktarı

\section{Introduction}

Potato is an important carbohydrate source with its starch storage attribute in its tubers. Stored starch molecules provide the energy source of the plant. The starch is transformed into sugar to provide the energy required for plant growth and development. It is of considerable importance that the starch stored during growing period reaches the next planting period with minimum loss after harvest. Potato tuber, with the breaking of dormancy, begins to convert the stored starch into sugar for shoot development. It is not desirable, however, to break the dormancy of seed tubers kept in storage until planting (Er and Uranbey, 2009; Alexopoulos et al., 2015). Storage temperature and humidity are important factors for regulating dormancy and sprouting. If the appropriate storage temperature is not provided, the dormant state of the tubers is short-term and the tubers, therefore, show early shoot development before planting. Sprouting of the tubers stored for fresh consumption reduces the market value of potatoes. Furthermore, sprouting tubers are not desirable for planting in potato cultivation. Effective control of sprouting is critically important for preservation of potato quality under storage conditions (Kara, 2004; Gomez et al., 2013). Various studies using several hormones and mineral elements have been carried out in order to complete the storage period with the least losses in stored tubers (Hernández-Muñoz et al., 2006; Akhtar et al., 2010). Calcium is one of the elements used for this purpose (Gonzales and Quevedo, 2017; Javed et al., 2018). Previous studies show that calcium plays a critical role in maintaining cell wall hardness and helps prevention of deteriorations of the tuber skin and damages in the walls of epidermal cells (Kassem et al., 2014, Madani et al., 2016). This research was intended with the thought that using certain calcium applications physiological and chemical changes occurring in potato tubers during storage could be kept to a minimum level so that economic losses in market value be prevented. The purpose of this study is to determine the effects of pre-storage calcium applications on changes in physiological and chemical characteristics of potato tubers during storage.

\section{Material and Methods}

This research was carried out in a cold storage using 85-90\% relative humidity and $4{ }^{\circ} \mathrm{C}$ temperature at Agricultural Faculty of Ordu University. Agria, a certified variety obtained from a private seed company, was used as the plant material. The experiment was carried out in completely randomized design with three replications. Before the application process, potato tubers were kept in solution containing $10 \%$ sodium hypochlorite for 5 minutes and passed through pure water. Calcium chloride $\left(\mathrm{CaCl}_{2}\right)$ was used as calcium source. The tubers were then treated with the solutions containing 5\%, 10\% and 15\% calcium and the tubers in the control group was treated with pure water. After dipping in solutions for one hour, the tubers were dried on blotting papers and placed in storage medium using storage boxes. Tuber samples were taken every 45 days for analyzes. The shooting rate and shoot length observations were taken at the end of the 135th day. For total sugar rate, $500 \mu \mathrm{L}$ from each potato supernatant was diluted with $500 \mu \mathrm{L}$ distilled water and $500 \mu \mathrm{L}$ phenol solution and 2.5 $\mathrm{ml}$ sulfuric acid were added to the flasks. Absorbance values were determined at $760 \mathrm{~nm}$. The absorbance values were evaluated according to the glucose standard and expressed as percentage (Dubois et al., 1956). For total phenolic content, $1000 \mu \mathrm{L}$ from each potato supernatant was diluted with $3.6 \mathrm{~mL}$ distilled water and $100 \mu \mathrm{L}$ Folin-Ciocalteu reagents were added to $300 \mu \mathrm{L} \mathrm{Na}_{2} \mathrm{CO}_{3}$. Absorbance values were determined at $760 \mathrm{~nm}$. The standard was Gallic acid. The values were evaluated as milligrams (mg) of gallic acid equivalents (GAE) per grams (g) of fresh weight (fw) (Beyhan et al., 2010). DPPH (1,1diphenyl-2-picryl-hydrazil) solution was prepared for DPPH analysis by modifying the method of Brand-Williams et al. (1995). It was added $1 \mathrm{ml}$ of DPPH solution with a concentration of $0.26 \mathrm{mM}$ to $1000 \mu \mathrm{L}$ tuber extract and $2000 \mu \mathrm{L}$ of ethyl alcohol, followed by $30 \mathrm{~min}$. kept in the dark. Absorbance values were determined at $517 \mathrm{~nm}$. The values were evaluated as a fresh weight (TE $\mathrm{g}^{-1} \mathrm{fw}$ ) of $100 \mathrm{~g}^{-1}$ equivalents to $\mu$ mol Trolox. SAS-JMP-5.01 package program was used for the significant difference test. LSD-test (least significance difference test) was applied for multiple comparison. 


\section{Results and Discussion}

According to the results of this study, shooting rate decreased with increasing calcium doses (Fig. 1). Shooting rates were obtained from the control, $5 \%$, $10 \%$ and $15 \%$ calcium as $97.1 \%, 83.93 \%, 83.6 \%$ and $80.93 \%$, respectively. It was determined that shooting rate of $5 \%$ calcium application was $7 \%$ lower than that of the control. The lowest shooting rate was obtained from $15 \%$ calcium application. At the end of the storage, the shoot lengths were found to be as $24.3 \mathrm{~mm}, 11.16 \mathrm{~mm}, 8.16 \mathrm{~mm}$ and $11.8 \mathrm{~mm}$ at the control, 5\%, 10\% and 15\% calcium doses, respectively (Fig. 2). Calcium doses, except for the control, were statistically in the same group. Calcium application of $10 \%$ decreased shoot length by approximately $67 \%$ compared to the control. It is known that the application of calcium reduces continuing respiratory rate after harvest of stored plants such as apples, radishes, broccoli and melons (Kou et al., 2015; Ranjbar et al., 2018). Reduction of respiration may prevent the breakdown of polysaccharides within the storage organ (Öztürk et al., 2016). The disintegrated polysaccharides are transported to shoots. It can be thought that the shoot formation and development of potato tuber may be due to increased respiration (Benkeblia et al., 2008). In view of the results of this study, it was thought that calcium could prevent early shoot formation and development by decreasing the amount of respiratory rate during storage.

The minimum sugar content was obtained from the tubers treated with the $10 \%$ calcium dose at the storage period of 45, 60, and 135 days (Fig. 3-4). The mean minimum increase in the amount of sugar was obtained as $15 \%$ from the $10 \%$ calcium dose. This increase was $31 \%$ in non-treated tubers. It is generally stated that the amount of sugar contained in potato tubers increases with increasing duration in long-term storage (Kaul et al., 2010; Bhattacharjee et al., 2014). The sugars formed by the breakdown of polysaccharides can easily be used for shoot formation in potato tubers. Thus, it is undesirable to increase sugar content in potatoes, especially at low temperatures, during the desired storage time. Previous studies have shown that pre-storage applications of potato tubers can prevent the increase in sugar content during storage (Lester and Grusak, 2004; Kaur et al., 2012; Foukaraki et al., 2014). As far as we know, there is no study about the effects of calcium on above mentioned parameters of potato. Lara et al. (2004) and Jagadeesha et al. (2015) reported that the increases in sugar ratio of bananas and strawberry treated with calcium chloride were lower than those in the control fruits.

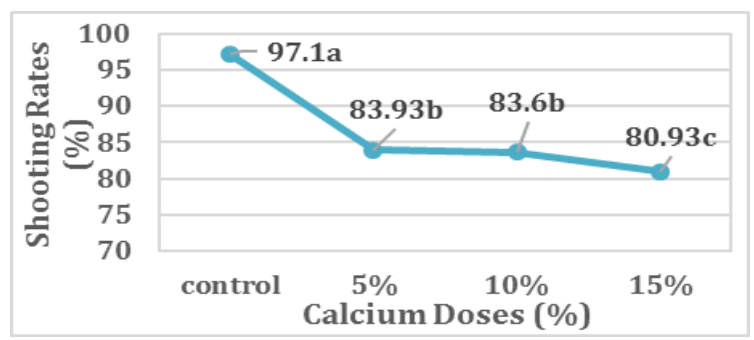

Figure 1. Shooting rate (\%) of potato with applied calcium before storage at the end of the storage

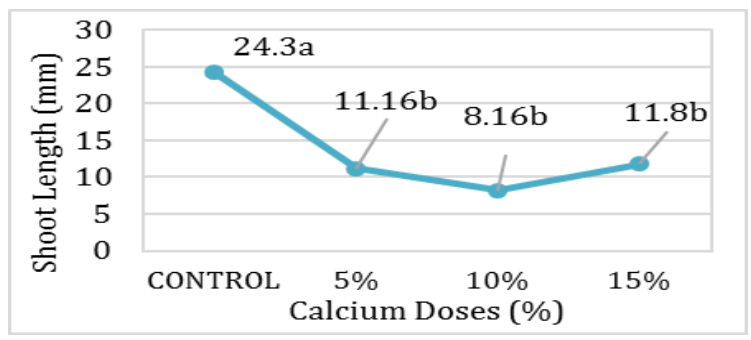

Figure 2. Shoot length $(\mathrm{mm})$ of potato with applied calcium before storage at the end of the storage

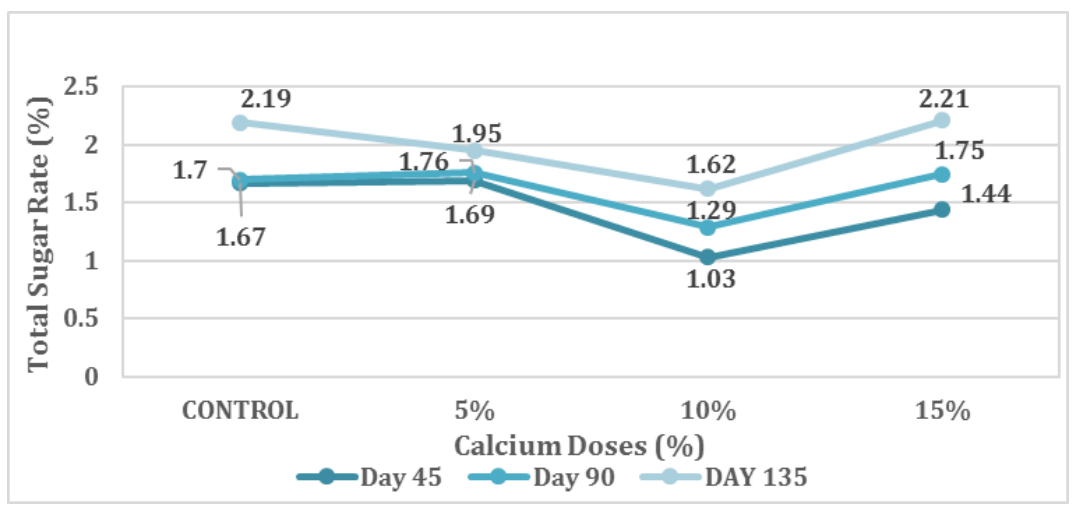

Figure 3. Total sugar rates of potato with applied calcium before storage for day 45, day 90 and day 135 during storage 


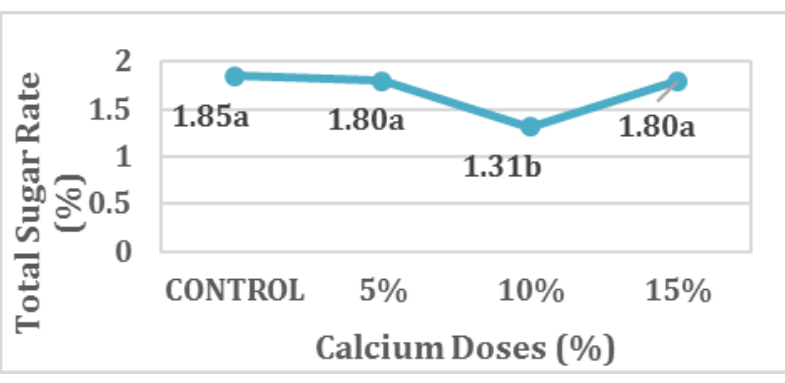

Figure 4. Total sugar average values of potato with applied calcium before storage at the end of the storage

As a result of this study, it was observed that the amount of total phenolic content (TPC) decreased with increasing storage time (Fig. 5). This is the same for DPPH used to determine antioxidant activity (Fig. 7). It is well-known that there is a positive correlation between total phenolics and antioxidant activity (Ay et al., 2018). The greatest values of total phenolic content and the highest antioxidant activity values were obtained from the tubers treated with $15 \% \mathrm{CaCl}_{2}$ compared with the control (Fig. 6-8). The tubers treated with 5\% and $10 \% \mathrm{CaCl}_{2}$ were found to have more TPC and more antioxidant activity than the control after storage. Phenolic compounds and antioxidants in plants can protect cells against oxidative injury by destroying free radicals (Jiménez-Zamora et al., 2016; Huyut et al., 2017). In previous studies, it was determined that pre-harvest and post-harvest applications of calcium could provide a high rate of total phenolics and antioxidant activity in the stored part of the plant compared to the control (Shafiee et al., 2010; Madani et al., 2016). Bagheri et al. (2015) reported that total phenolic contents and antioxidant activities of persimmon fruits treated with calcium at the end of storage were more than that of the control.

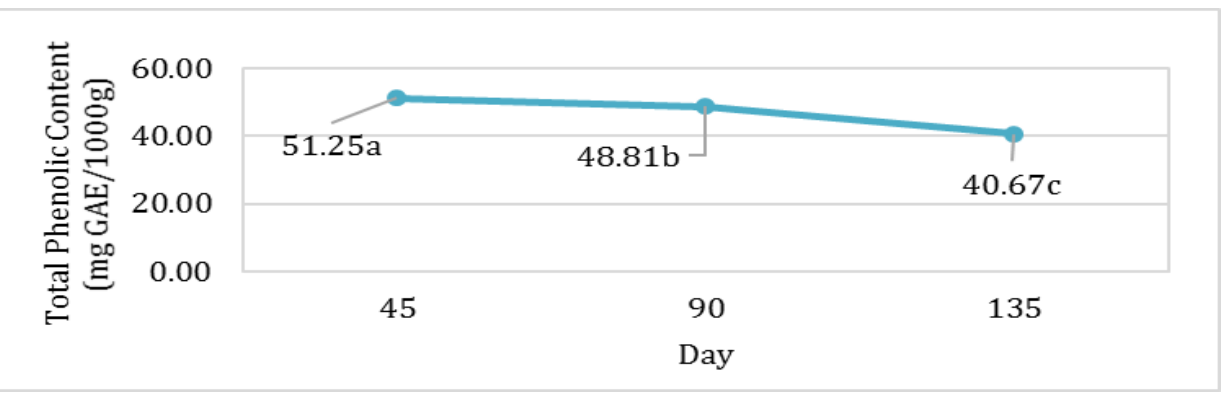

Figure 5. Total phenolic content of potato day 45, day 90 and day 135 at storage

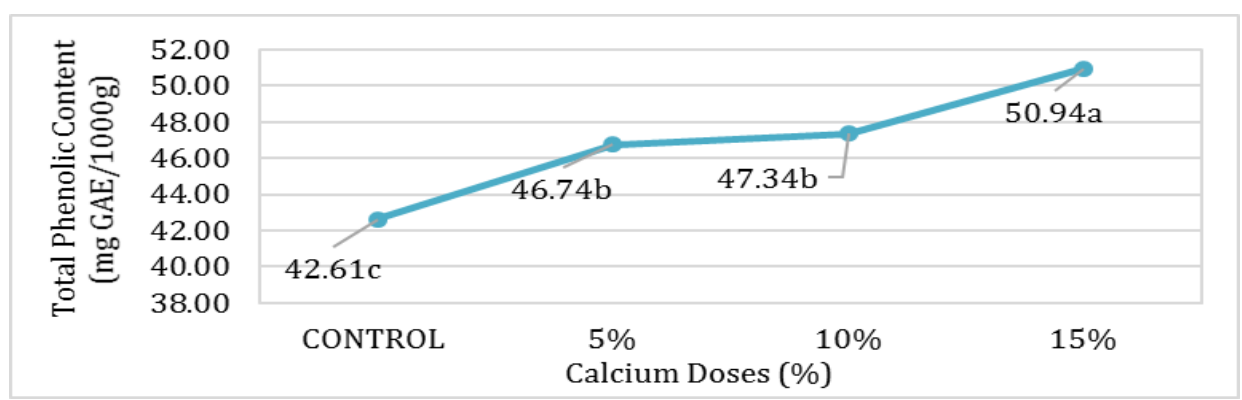

Figure 6. Total phenolic content of potato with applied calcium before storage at the end of the storage

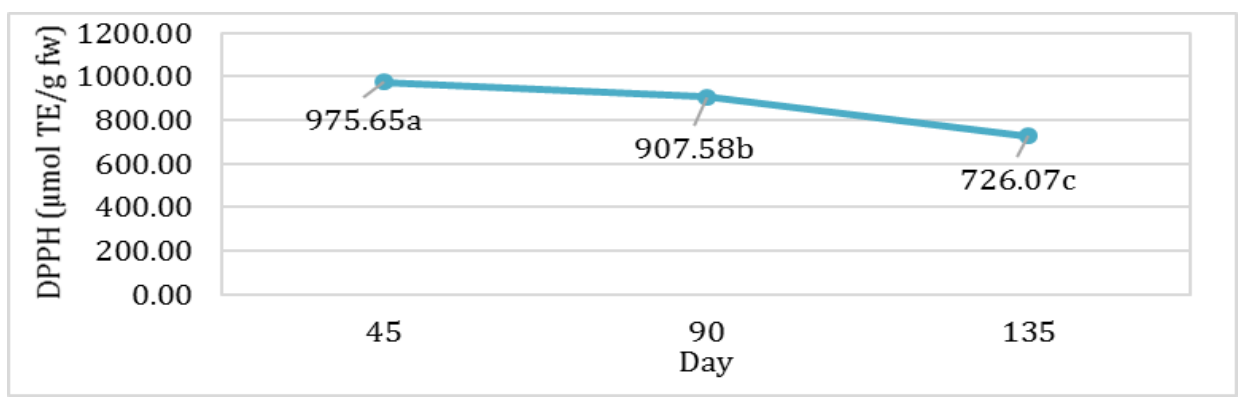

Figure 7. DPPH of potato with applied calcium before storage for day 45, day 90 and day 135 at storage 


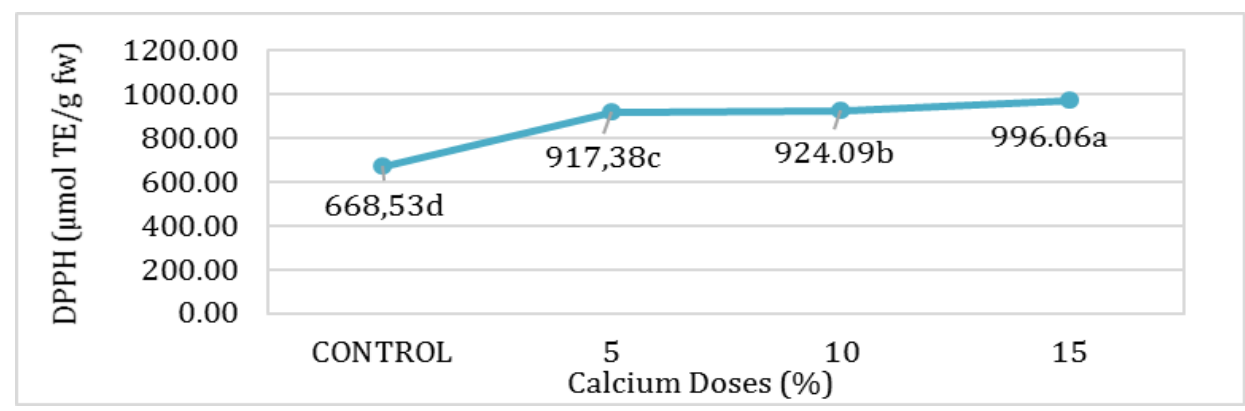

Figure 8. DPPH of potato with applied calcium before storage at the end of the storage

\section{Conclusion}

The results of this study revealed that postharvest calcium application was effective on inhibiting or slowing down the increase in sugar rate. It can be concluded that dipping potato tubers in $\mathrm{CaCl}_{2}$ solutions may help prolong postharvest life of the potato tubers in cold storage. The dipping application of calcium played an important role at preventing of early shooting during cold storage. In addition, as a result of this study, it is thought that it is possible to prevent the decrease of phenolic compounds and antioxidants in stored potato tubers by calcium pre-applications.

\section{References}

Akhtar, A., Abbasi. N. A., Hussain. A., 2010. Effect of calcium chloride treatments on quality characteristics of loquat fruit during storage. Pakistan Journal of Botany, 42(1): 181-188.

Alexopoulos, A. A., Karapanos, I. C., Akoumianakis, K. A., Passam, H. C., 2014. Effect of postharvest application of plant growth regulators on the storage life of tubers grown from true potato seed (TPS). Acta Hort., 1079: 627-631.

Ay, E. B., Gül, M., Açikgöz, M. A., Yarilgaç, T., Kara, Ș. M., 2018. Assessment of antioxidant activity of giant snowdrop (Galanthus elwesii Hook) extracts with their total phenol and flavonoid contents. Indian Journal of Pharmaceutical Education and Research, 52: 128-132.

Bagheri, M., Esna-Ashari, M., Ershadi, A., 2015. Effect of postharvest calcium chloride treatment on the storage life and quality of persimmon fruits (Diospyros kaki Thunb.) cv. 'Karaj'. International Journal of Horticultural Science and Technology, 2(1): 15-26.

Benkeblia, N., Alexopoulos, A. A., Passam, H. C., 2008. Physiological and biochemical regulation of dormancy and sprouting in potato tubers (Solanum tuberosum L.). Fruit, Vegetable and Cereal Science and Biotechnology, 2: 54-68.

Beyhan, Ö., Elmastaş, M., Gedikli, F., 2010. Total phenolic compounds and antioxidant capacity of leaf, dry fruit and fresh fruit of feijoa (Acca sellowiana, Myrtaceae). Journal of Medicinal Plants Research, 4: 1065-1072.

Bhattacharjee, A., Roy, T. S., Haque, M. N., Pulok, M. A. I., Mahfuzar, M., 2014. Changes of sugar and starch levels in ambient stored potato derived from TPS. International Journal of Scientific and Research Publications, 4(11): 1-5.

Brand-Williams, W., Cuvelier, M. E., Berset, C. L. W. T., 1995. Use of a free radical method to evaluate antioxidant activity. LWT-Food science and Technology, 28(1): 25-30.

Dubois, M., Gilles, K. A., Hamilton, J. K., Rebers, P. T., Smith, F., 1956. Colorimetric method for determination of sugars and related substances. Analytical Chemistry, 28(3): 350-356.

Er. C., S. Uranbey., 2009. Nişasta ve Şeker Bitkileri. Ankara Üniversitesi Ziraat Fakültesi Yayın No:1573. Ankara.

Foukaraki, S. G., Cools, K., Chope, G. A., Terry, L. A., 2014. Effect of the transition between ethylene and air storage on post-harvest quality in six UK-grown potato cultivars. The Journal of Horticultural Science and Biotechnology, 89(6): 599-606.

Gomez-Castillo. D., Cruz. E., Iguaz. A., Arroqui. C. Vírseda. P. 2013. Effects of essential oils on sprout suppression and quality of potato cultivars. Postharvest Biology and Technology, 82: 15-21.

Gonzales, L. M. R., Quevedo, M. A., 2017. Respiration rate and shelf life of radish (raphanus sativus l.) as influenced by postharvest application of calcium nitrate and humic acid concentration. Mindanao Journal of Science and Technology, 15: 76-88.

Hernández-Muñoz. P., Almenar. E., Ocio. M. J., Gavara., R., 2006. Effect of calcium dips and chitosan coatings on postharvest life of strawberries (Fragaria $\mathrm{x}$ 
ananassa). Postharvest Biology and Technology, 39(3): 247-253.

Huyut, Z., Beydemir, Ş., Gülçin, İ., 2017. Antioxidant and antiradical properties of selected flavonoids and phenolic compounds. Biochemistry Research International, 2017: 1-10.

Jagadeesha, M., Soorianathasundaram, K., Kumar, V. H., Harikanth, P., Deepika, C., 2015. Postharvest quality enhancement of plantain cv. Nendran by using different growth regulators and chemicals. Plant Archives, 15(1): 75-80.

Javed, M. S., Randhawa, M. A., Ahmad, Z., Sajid, M. W., Nasir, M. A., Tariq, M. R., 2018. Effect of $\mathrm{CaCl} 2$ and controlled atmosphere storage on phytochemical attributes of Guava. Food Science and Technology, 38(2): 356-362.

Jiménez-Zamora, A., Delgado-Andrade, C., Rufián-Henares, J., A., 2016. Antioxidant capacity, total phenols and color profile during the storage of selected plants used for infusion. Food Chemistry, 199: 339-346.

Kara, K., 2004. Bazı patates çeşitlerinin depolama sonrası kalite ve fizyolojik özelliklerinin incelenmesi. Gida Dergisi, 29(1): 63-71.

Kassem. H. A. A. R. Al-Harbi., MS DhaifAllah, 2014. Effect of salicylic acid and/or calcium chloride on potato tubers and quality and storage potential. htps://www.academia.edu/19218155/Effect_of_Sa licylic_Acid_andor_Calcium_Chloride_on_Potato_Tu bers_and_Quality_and_Storage_Potential

Kaul, A. D., Kumar, P., Hooda, V., Sonkusare, A., 2010. Biochemical behaviour of different cultivars of potato tuber at different storage conditions. In National Conference on Computational Instrumentation CSIO Chandigarh, India, 172-176.

Kaur, S., Sandhu, K. S., Aggarwal, P., 2012. Chlorpropham affects processing quality of potato during storage.
International Journal of Vegetable Science, 18(4): 328-345.

Kou, L., Yang, T., Liu, X., Luo, Y., 2015. Effects of pre-and postharvest calcium treatments on shelf life and postharvest quality of broccoli microgreens. Journal of the American Society for Horticultural Science, 50(12): 1801-1808.

Lara I., Garcıa. P., Vendrell. M., 2004. Modifications in cell wall composition after cold storage of calciumtreated strawberry (Fragaria $\times$ ananassa Duch.) fruit. Postharvest Biology and Technology. 34(3): 331-339.

Lester, G. E., Grusak, M. A., 2004. Field application of chelated calcium: postharvest effects on cantaloupe and honeydew fruit quality. HortTechnology, 14(1): 29-38.

Madani, B., Mirshekari, A., Yahia, E., 2016. Effect of calcium chloride treatments on calcium content, anthracnose severity and antioxidant activity in papaya fruit during ambient storage. Journal of the Science of Food and Agriculture, 96(9): 2963-2968.

Öztürk, E., Polat, T., Tarakçı, S., 2016. Depolamanın bazı patates (Solanum tuberosum l.) çeşitlerinin fiziksel özelliklerine etkisi. Journal of the Faculty of Ataturk Universíty Agriculture, 47(2): 89-94.

Ranjbar, S., Rahemi, M., Ramezanian, A., 2018. Comparison of nano-calcium and calcium chloride spray on postharvest quality and cell wall enzymes activity in apple cv. Red Delicious. Scientia Horticulturae, 240: 57-64.

Shafiee, M., Taghavi, T. S., Babalar, M., 2010. Addition of salicylic acid to nutrient solution combined with postharvest treatments (hot water, salicylic acid, and calcium dipping) improved postharvest fruit quality of strawberry. Scientia Horticulturae, 124(1): 40-45. 